\title{
Güncel Pazarlama Yaklaşımlarının Sağlık Hizmetlerinde Uygulanabilirliği
}

\section{The Application of Contemporary Marketing Approaches in the Health Services}

\author{
Dr. Öğr. Üyesi Gülcan ŞANTAŞ ${ }^{\text {ID }}{ }^{1}$, Dr. Öğr. Üyesi Fatih ŞANTAŞ (D) 2
}

\begin{abstract}
$\ddot{\mathbf{O z}}$
Sağlık hizmetlerinin kendine özgü özellikleri nedeniyle sağlık hizmetlerinde pazarlama faaliyetleri diğer hizmet sektörlerinden farklılaşmaktadır. Sağlık hizmeti pazarlaması; sağlık hizmeti sunucularının sayısının artması, artan tıbbi maliyetler ve tıbbi odakların değişmesi gibi zorluklarla rekabetçi bir şekilde nasıl başa çıkılabileceğine dair bir anlayış sağlamaktadır. Sağlık hizmetleri pazarlamasına yönelik eleştiriler olmakla birlikte, her türlü hizmette olduğu gibi sağlık hizmetlerinde de memnuniyeti yaratma ve sadakat oluşturmada hizmet pazarlamasının temel ilkeleri ve yönleri katkı sağlayabilmektedir. Bu çalışmada güncel pazarlama yaklaşımlarından nöropazarlama, viral pazarlama, gerilla pazarlama ve dijital pazarlama stratejilerine yer verilmektedir. Ayrıca çalışmada güncel pazarlama yaklaşımlarının sağlıkta uygulanabilirliği örnekler üzerinden tartışılmaktadır. Hastalıkların erken teşhisinde ve sağlığın geliştirilmesi hizmetlerinde bu çalışmada bahsedilen güncel pazarlama yaklaşımlarından daha fazla yararlanılabileceği söylenebilir.
\end{abstract}

Anahtar Kelimeler: Güncel pazarlama yaklaşımları, sağlık hizmetleri pazarlaması, sağlık kurumları

Makale Türü: Derleme

\begin{abstract}
Marketing activities in the health services are different from other service sectors due to the unique characteristics of health services. Health care marketing provides an understanding of how to cope with the challenges of increasing number of health care providers, increasing medical costs and changing medical focus in a competitive way. Although there are criticisms about health care marketing, the basic principles and aspects of service marketing can contribute to creating satisfaction and loyalty in health services as in every kind of service. In this study, neuromarketing, viral marketing, guerilla marketing and digital marketing strategies are included in the current marketing approaches. In addition, the applicability of current marketing approaches in health is discussed through examples. It can be said that the current marketing approaches mentioned in this study can be used more in the early diagnosis of diseases and health promotion services.
\end{abstract}

Keywords: Current marketing approaches, health care marketing, health care organizations

Paper Type: Review

\footnotetext{
${ }^{1}$ Yozgat Bozok Üniversitesi, İktisadi ve İdari Bilimler Fakültesi, gulcan.santas@ bozok.edu.tr.

${ }^{2}$ Yozgat Bozok Üniversitesi, İktisadi ve İdari Bilimler Fakültesi, fatih.santas@bozok.edu.tr.
}

Atıf için (to cite): Şantaş, G., \& Şantaş, F. (2020). Güncel pazarlama yaklaşımlarının sağlık hizmetlerinde uygulanabilirliği. Afyon Kocatepe Üniversitesi Sosyal Bilimler Dergisi, 22(2), 432-443. 


\section{Giriş}

Sağlık hizmetleri pazarlaması, hedef pazarın ihtiyaç ve isteklerini anlama süreci olarak ifade edilmektedir ve sağlık hizmetleri sunum sisteminin örgütlenmesi, analiz edilmesi, planlanması, planların uygulanması ve kontrol edilmesi süreçlerini bir araya getiren bir bakış açısı sunmaktadır. Sağlık hizmetleri pazarlaması sürecinin çıktısı, bireylerin sağlıklılık hallerine katkı sağlanması, sağlı hizmeti sunucuları ile hedef pazar arasında değer değişiminin kolaylaştırılması ve hedef pazarı memnun etmenin yollarının geliştirilmesidir (Cooper, 1994, s. 7).

Sağlık hizmetlerinde pazarlama araçları; sağlık hizmeti sunucuları, tüketiciler ve hükümetler arasında ortak sağlık bilgisinin yaygınlaşmasına yardımcı olarak bu taraflar arasında bağlantı sağlamada önemli rol oynamaktadır. Sağlık hizmeti pazarlaması ile hastaların sağlık düzeylerinin yükseltilmesine, sağlık hizmeti kalitesi, memnuniyeti, kaygısı veya belirsizliği konusundaki kaygı verici sorunlarına yardımcı olunmaktadır. Sağlık hizmeti pazarlaması; sağlık hizmeti sunucularının sayısının artması ve artan maliyetler gibi zorluklarla rekabetçi bir şekilde nasıl başa çıkılabileceğine dair bir anlayış sağlamaktadır. İyi bir pazarlama karması oluşturmak ve bölümlendirme, hedefleme ve konumlandırma yöntemlerini kullanmak gibi pazarlama araçları ve kavramları, sağlı sistemlerinin daha etkin ve verimli bir şekilde sunulmasını sağlayabilmektedir (Lim ve Ting, 2012, s. 3).

Sağlık kurumlarının pazarlamaya yatırım yapmalarının iki önemli sebebinin bulunduğu söylenebilir: İlk sebep, hastaneler ve diğer sağlık kuruluşları saygın bir markanın gücünü anlamaya başlamıştır ve tüketiciler bugün daha fazla bilgiye sahiptir. Hastaneler, piyasadaki pozisyonlarını kendileri belirleyemezlerse, pozisyon ağızdan ağza pazarlama yoluyla rakipler ve ulaşabildikleri veri ve bilgiler yoluyla tüketiciler tarafindan belirlenmektedir. Hastaneler, poliklinikler ve ameliyat merkezleri gibi seçenekler düşünüldügünde, tüketiciler çok fazla alternatife sahiptir. Daha iyi bir fiyat, daha iyi imkânlar, daha iyi bir hekim ya da istedikleri sağlık hizmetlerini almak için tüketiciler ülke çapında ve günümüzde gittikçe artan önemiyle farklı ülkelere tıp hizmeti almak için sağlık turizmi adı altında seyahat edebilmektedir. Dolayısıyla tüketicilerin artan seçenekleri sağlık kurumlarında rekabeti daha önceki dönemlere göre artırmıştır. Sağlık kurumları bu rekabet ortamında yalnızca yüksek teknoloji ve ülke yasal mevzuatında kendilerine izin verilen ölçüde iletişim araçları aracılığıyla mesajlar iletmelidir (Berney, 2015).

Gelişmiş ve gelişmekte olan ülke sağlik sistemlerinde tartışılan gündem maddelerinden biri olan sağlık hizmetleri pazarlaması, çeşitli şekillerde eleştirilmektedir. Sağlık kurumlarında pazarlamaya karş1 yöneltilen eleştiriler şu şekilde sıralanabilmektedir (Karafakıoğlu, 1998, s. 1821):

- Sağl1k hizmetleri talebinde pazar güçlerinin etkisi diğer mal ve hizmetlerde olduğu gibi baskın değildir.

- Sağlık hizmetlerinde pazarlama kıt kaynakların boşa harcanmasına neden olabilir.

- Pazarlama saldırgandır ve bu sebeple kişi ve aile mahremiyetine saygı duymayarak toplumda huzursuzluk oluşturabilmektedir.

- Pazarlama, talebi oluşturmada yönlendirici olabilmektedir. Özellikle estetik cerrahi gibi alanlarda gereksiz talebe neden olabilmektedir.

- Pazarlama, sağlık hizmeti kalitesinin düşmesine sebep olabilmektedir.

- Sağlık hizmetlerinde pazarlama rekabeti tetikleyebilmektedir ve bu rekabet sağlık hizmeti sunucuları arasında bilimsel işbirliğini engelleyebilmektedir.

- Sağlık hizmetlerinde pazarlama faaliyetleri hastalar arasında ayrım yapılmasına da yol açabilmektedir. 
Türkiye'de sağlıkta pazarlama faaliyetleri ve reklamlar ile ilgili yaptırımlar bulunmaktadır. Tababet ve Şuabatı Sanatlarının Tarzı İcrasına Dair Kanun, Tüketicinin Korunması Hakkında Kanun, Ticari Reklam ve İlanlara İlişkin İlkeler ve Uygulama Esaslarına Dair Yönetmelik gibi birçok kanun ve yönetmelik, sağlık hizmetlerinde reklam ve pazarlama faaliyetlerine kısıtlama getirmektedir (Ağırbaş ve diğ., 2011, s. 129; Santas et al. 2017, s. 2).

Ancak sağlık hizmetlerinde hastalıklar konusunda farkındalığı artırmak ve sağlığın geliştirilmesine yönelik hizmetleri teşvik etmek için sosyal pazarlama faaliyetleri katkı sağlayabilmektedir. Sağlık hizmetleri pazarlamasına yönelik eleştiriler olmakla birlikte, her türlü hizmette olduğu gibi sağlık hizmetlerinde de memnuniyeti artırma ve sadakat oluşturmada hizmet pazarlamasının temel ilkeleri ve yönleri katkı sağlayabilmektedir. Ancak sağlık sektöründe hizmet sunumuyla ilişkili karmaşıklıklar ve farklılıklar, elde edilen hasta memnuniyetinin derecesini belirlemek için gerekli olan kapsamlı değerlendirme, kıyaslama ve izleme mekanizmalarını gerektirmektedir (Corbin et al. 2001, s. 2).

Yakın gelecekte sağlık hizmetleri pazarlamasının daha fazla gündeme geleceği tahmin edilmektedir. Bunun sebepleri şu şekilde sıralanmaktadır (Lim ve Ting, 2012, s. 3):

- Sağlık hizmeti değer zincirinin farmasötik, biyoteknoloji ve terapötik endüstrilerden oluşan yaşam bilimleri için önemli olacağı anlaşılacaktır.

- Hasta memnuniyeti ölçümünün iyileştirilmesi ve hasta sadakatinin önemi artan konu başlıkları arasında olacaktır. Bu sebeple, süreç ve sonuçlara dayalı bakım ile hastalıklara özgü ve genel memnuniyetin ölçülmesi için rafine edilmiş araçlara ihtiyaç duyulmaktadır. Ayrıca bölümlendirme, hedefleme ve konumlandırma araçları gibi çeşitli pazarlama araçları kullanılarak, farklı sağlık tüketicilerini hedefleyen sağlık çözümleri geliştirilmesi gündeme gelecektir. Böylece sağlık hizmetleri pazarlaması maliyetleri azaltmaya ve daha uzmanlaşmış hizmet sunumuna katkı sağlayabilecektir.

- Pazarlamanın, sağlık hedefleri ve sağlığın geliştirilmesi konularında etkisi artacaktır. Günümüzde de çok tartışılan sağlıklı davranışlar ve yaşam tarzlarını benimsemede ve teşvik etmede sağlı pazarlamasının daha aktif şekilde kullanılmaya başlanacağı tahmin edilmektedir.

- Sağlık turizminin artan hacmi düşünüldüğünde markalaşma, hedef pazarlama ve sosyal medyanın kullanımı gibi konularda sağlık hizmeti pazarlamasında yeni trendler gündeme gelecektir.

Bu çalışmada güncel pazarlama yaklaşımlarından nöropazarlama, viral pazarlama, gerilla pazarlama ve dijital pazarlama stratejilerine yer verilmektedir. Ayrıca çalışmada güncel pazarlama yaklaşımlarının sağlıkta uygulanabilirliği örnekler üzerinden tartışılmaktadır. $\mathrm{Bu}$ çalışma ile pazarlama yaklaşımlarının sağlık sektörü örnekleri incelenerek alanyazına katkı sağlanması amaçlanmaktadır.

\section{Nöropazarlama}

Sinirbilimi disiplininin ortaya çıkardığı nöropazarlama tekniği, beyin temelli anlatıların gelişimini incelemekte ve kullanmaktadır (Fisher et al. 2010, s. 1). İnsan beyni, vücudumuzun en karmaşık yapısıdır. Beyin sinapsları deneyim ve öğrenme ile değişmektedir. Nöropazarlama, pazarlama alanında çalışan araştırmacılar için farklı yaş veya eğitim seviyesi gibi özellikler üzerinde çalışırken farklı çerçeveler sunmaktadır (Kumar et al. 2016, s. 5). Nöropazarlama, tüketicilerin uyarıcılara olan tepkilerini gözlemeyi amaçlayan teknoloji temelli pazar araştırmalarıdır (Flores et al. 2014, s. 77). Pazarlama uzmanları; nöropazarlama tekniklerini kullanarak tüketicinin duygularını, hislerini, beklentilerini ve hatta gizli kısıtlamalarını keşfedebilmektedir (Orzan et al. 2012, s. 428).

Nöropazarlama, son yıllarda sağlı kurumlarında pazarlama yaklaşımları arasında dikkat çeken konu başlıklarından biridir. Bu pazarlama türünde, sağlık tüketicilerinden doğru bilginin elde edilmesinde fizyolojik ölçümlerden faydalanılmakta ve bir takım teknolojik cihazlar 
kullanılmaktadır. Nöropazarlamada kullanılan başlıca teknolojiler şu şekildedir: fMRI (Fonksiyonel Manyetik Görüntüleme Cihazı), PET (Pozitron Emisyon Cihazı), EEG (Elektro Beyin Grafiği Cihazı), Eye Tracking (Göz tarama), GRS (Galvanic Deri Tepkisi Cihazı), PDR (Gözbebeği Genişletme Tekniği), SST (Steady State Probe Topography), MEG (Magnetoencepholography). Bu teknikler, bireyin sağlık ve sosyal nedenli pazarlama kampanyalarına dâhil olma kararının arkasındaki gizli itici güçleri belirleme potansiyeline sahiptir. Tekniğin uygulanmasında genellikle odak grupları ve derinlemesine görüşmeler gibi nitel araştırma yöntemleri kullanılmaktadır ancak nicel araştırmalar ve deneyler de yap1labilmektedir (Harris et al. 2018, s. 4).

Sağl1k sektörü ve ilaç endüstrisi; hizmetlerin sunumunda, ürünleri satmada ve reklam vermede yeni zorluklarla karşı karşıyadır. Yenilikçi ameliyatlar ve tıbbi ilerlemeler daha fazla tartışılmaktadır ve piyasada rekabet giderek artmaktadır. Bu bağlamda, sağlık sektöründe pazarlamanın rolü artış göstermektedir. Tüketici beklentilerinin giderek önemli hale geldiği sağlık sektöründe, nöropazarlamanın sağlık kurumlarının rekabet edebilirliğine gelecekte daha fazla yardımcı olması beklenmektedir (Kumar et al. 2016, s. 6-7; Orzan et al. 2012, s. 428).

Nöropazarlama ilaç sektöründe kullanılmakla birlikte bu tekniklerin kullanımı hakkında çok az bilgi paylaşılmaktadır. Etik açıdan, birçok şirket detayları açıklamamayı tercih etmektedir. Ancak birçok ilaç şirketinin ön testleri yapmak ve en etkili televizyon ilaç reklamlarını seçmek için nöropazarlama tekniklerini kullandığ 1 belirtilmektedir. Nöropazarlama tekniklerinin kullanımıyla ilaç şirketinin görebileceği potansiyel zarar en aza indirilmeye çalışılmaktadır. Potansiyel tüketicilerin bilinçli ve bilinçsiz zihni anlaşılarak, gelecekteki projelerde bu bilgiler kullanılabilmektedir. İlaç şirketleri nöropazarlamanın yardımıyla sağlık tüketicileri ile ilgili şu bilgileri elde edebilmektedir (Orzan et al. 2012, s. 428-430):

- Hangi reklamların daha cazip bulunduğu ve daha az izlendiği,

- Reklamların hangi bölümlerinin daha akılda kalıcı olduğu ve potansiyel tüketiciyi duygusal olarak ilgilendirdiği,

- Farklı reklamların hangi duyguları ortaya çıkardığı,

- Her bir reklam için beynin faaliyetlerini kaydetme ve bu faaliyetleri izleme.

fMRI gibi nöro-görüntüleme teknikleri, çağdaş sinirbilimde hem hastalık süreçlerini hem de bilişsel olguların temel fizyolojisini incelemek için çeşitli yaklaşımlar sunmaktadır. Klinik alanda nöro-görüntüleme tekniklerini kullanmak; ilaç gelişimini izlemek ve erken aşamalarda hastalıkların tanısına ve tedavisine yeni yaklaşımlar sağlamak için umut olmaktadır (Racine et al. 2005, s. 159). Ancak bir başka açıdan bakıldığında bu tür taramalar ciddi etik soruları gündeme getirmektedir. Guardian'da yayınlanan bir yazıda, davranışları tahmin etmek için beyin taramalarını kullanmanın sorunlu bir yol olduğu ve bu gelişmelerin etkileri hakkında düşünmek gerektiği belirtilmektedir (Sample ve Adam, 2003).

Yakın gelecekte beyin görüntüleme teknolojisinin reklamlarda ve ticari ortamlarda daha fazla kullanılabileceği beklenmektedir. Ancak bu durumun bazı zararları olabileceği ifade edilmektedir. Beyin görüntüleme, kişisel mahremiyeti kabul edilemez bir dereceye kadar ihlal edebilmektedir. Dolayısıyla bu teknolojinin ticari kullanımını düzenlemek için yasal bir düzenlemeye ihtiyaç duyulacaktır (The Lancet Neurology, 2004, s. 71). Özellikle sağlık sektöründe kişisel mahremiyetin önemi düşünüldüğünde, nöropazarlama tekniklerinin potansiyel zararları olabilecektir.

Türkiye'de hem sağlık hizmetlerinin pazarlanmasında hem de diğer sektörlerde nöropazarlamanın kullanımında etik ikilemler bulunmaktadır. $\mathrm{Bu}$ açıdan bakıldı̆̆ında, nöropazarlamaya yönelik yapılacak ampirik araştırmalarda katılımcıların gönüllü olarak araştırmaya katılmayı kabul etmeleri önemli olmaktadır. Yürütülecek araştırmaların etik kurul onaylarının olması ve araştırma kapsamında deneklerin yasal haklarının sözleşmeler ile 
araştırmalar öncesinde belirlenmesi, diğer dikkat edilmesi gereken unsurlar arasındadır. Sağlık hizmetlerinde yürütülecek araştırmalarda Sağlık Bakanlığı'nın ve nörologların yer aldığı bir komisyonun izni mutlaka olmalıdır (Değirmen ve Şardağı, 2016, s. 156).

Türkiye'de nöropazarlama tekniğine örnek olarak eczacılık sektörüne ait bir reklam verilebilir. Bu şirketin bir ürününe ilişkin reklam, nöro-görüntüleme tekniklerinden olan göz takibi ve Elektroensefalografi cihazıyla değerlendirilmiştir. Araştırma 16 kadınla bir laboratuvar ortamında yürütülmüştür. Araştırmanın yapıldığı ortam oturma odası gibi tasarlanmış, kadınlara bu reklam izletilmiştir. İzleme sırasında ilk başlarda kadınların dikkat ve duygusal etkilenme durumu yüksek olurken; reklamın ilerleyen bölümlerinde yer alan bebeğin hareketleri, kadınların dikkat eğrisinde azalmaya yol açmıştır. Bu süreçte kadınlar kendilerinin çocuk yetiştirirken tecrübelerini hatırlamışlardır. Buradan hareketle nöropazarlama teknikleri kullanılarak ürünün beğenildiği, ancak ürüne ilişkin reklam mesajının tam dikkat eğrisinin yüksek olduğu zaman verilmesi gerektiği sonucuna ulaşılmıştır (Girişken, 2012; Nurdağ Silkü ve Şar, 2015, s. 41).

Nöropazarlama teknikleri, yukarıda örnekte olduğu gibi sağlık tüketicilerinin dikkat eğrisini ortaya koymakta kullanılabilir. Sağlıkta pazarlama yalnızca ilaç veya diğer sağlık ürünlerini satmak için değil, aynı zamanda sağlı̆ıı teşvik edilmesi ve geliştirilmesi amacıyla düzenlenen kamu spotu gibi uygulamalarda da araştırma katılımcılarının dikkat eğrilerini ortaya koymada kullanılabilir. Böylece yüksek bütçeler ile hazırlanan sağlığın geliştirilmesine yönelik obezite ile mücadele, tütün kullanımının azaltılması, uyuşturucu kullanımının önlenmesi gibi bilgilendirme yayınlarında mesajlar daha anlamlı ve doğru bir şekilde topluma iletilebilir.

\section{Viral Pazarlama}

Günümüzde tüketiciler, televizyon veya gazete reklamları gibi geleneksel reklam biçimlerine karşı direnç göstererek pazarlamacıların alternatif stratejilere yönelmesine sebep olmaktadır. Bu stratejilerden biri de viral pazarlamadır. Alanyazın incelendiğinde viral pazarlama yerine "virütik pazarlama", "virüsle pazarlama", "vızıltı pazarlaması" ve "bulaşıcı pazarlama" kavramları da kullanılmaktadır. Viral pazarlama, bir virüs hastalığı gibi ifade edilmektedir. Nasıl ki virüs kökenli bir hastalığa yakalanan kişi bu virüsü iletişimde bulunduğu diğer kişilere yayıyorsa, viral pazarlamada da verilmek istenen mesaj, kişinin iletişimde bulunduğu herkese yayması durumu söz konusu olmaktadır (Argan ve Tokay Argan, 2006, s. 232-233).

Viral pazarlama, tüketicileri ürün bilgilerini arkadaşlarıyla paylaşması konusunda teşvik etmektedir ve tüketiciler bunu yaparken mevcut sosyal ağlarını kullanmaktadır (Leskovec et al. 2007, s. 2). Bu pazarlama tekniği, bireylerin bir pazarlama mesajını başkalarına aktarmalarını teşvik eden ve mesajın etki alanında üstel büyüme potansiyeli yaratan her türlü stratejiyi ifade etmektedir. Viral pazarlama, genellikle pazarlamacının bir video veya mini site gibi elektronik içerikler oluşturmasıyla başlamaktadır ve bu pazarlama türünde genellikle marka oluşturmak amaçlanmaktadır (Ho ve Dempsey, 2010, s. 1000). Etkili bir viral pazarlama stratejisi şu unsurları içermektedir: Ürün veya hizmet hediye etmek, başkalarına zahmetsiz gönderim sağlamak, küçükten büyüğe kadar kolayca ölçeklemek, ortak motivasyon ve davranışlardan yararlanmak, mevcut iletişim ağlarını kullanmak ve diğer kaynaklardan yararlanmaktır (Wilson, 2018).

Viral pazarlama, son yıllarda şöhreti artan konular arasındadır ve bu pazarlama türüyle geniş kitlelerin dikkatini çeken kampanyalar oluşturulmaktadır. Sağlık kurumları, odak noktaları herkesin umursadığı bir konu (sağlı) olması nedeniyle viral pazarlamanın avantajından yararlanmak için oldukça uygun kurumlardır. Herkes kanserle savaşmak, sağlıklı şekilde yaşamak ve hastalıklarının tedavi olmasını istemektedir (Carter, 2018). Yalnızca kar amaçlı örgütler değil, aynı zamanda kar amacı gütmeyen örgütler de viral pazarlamayı etkili şekilde kullanmaktadır. Sağlık konusu ile ilgili çok sayıda mesaj, viral yayılma ile geniş kitlelere ulaştırılmaktadır (Argan ve Tokay Argan, 2006, s. 246).

Özellikle internet üzerinden viral pazarlama yazılım platformlarının kullanımı, sağlığın teşviki ile ilgili mesajların yaygınlaştırılması, yeni ve mevcut web kullanıcılarını elde etmede 
etkinlik açısından önemli rol oynamaktadır. İnternet üzerinden arkadaşlarıyla rekabet ederek ve sağlık ile ilgili sorulara cevap vererek "sağl1klı bir hediye paketi" kazanma olasıllı̆g 1 ve elektronik postaların iletilmesi amacıyla matematiksel algoritmaların kullanımı, sağlık sektöründe viral pazarlama tekniklerini kullanarak sağlığın teşviki çabalarına destek olabilmektedir (Gosselin ve Poitras, 2008, s. 10-11).

Yeni medya mesajları ve elektronik posta göndererek ve sosyal pazarlama siteleri üzerinden viral pazarlama tekniklerini kullanarak, yüz yüze görüşmeye ve iletişime gerek kalmadan kamu sağlığı kampanyaları ile ilgili tüketicilere bilgi verilebilmektedir (Parvanta et al. 2011, s. 231). Ayrıca fiziksel aktivitenin artırılmasını teşvik etmede viral pazarlama teknikleri katkı sağlayabilmektedir. Bu kampanyalar, hem daha basit yapılmaktadır hem de daha düşük maliyetli olmaktadır (Walji et al. 2009, s. 76-77). Dolayısıyla sağlık sektöründe viral pazarlamanın kullanımı, sağlığın teşviki ile ilgili politika ve uygulamaların bilinirliğini artırmada katk1 sağlayabilmektedir.

Bir sinir sistemi hastalığı olan Amiyotrofik Lateral Skleroz (ALS) hastalığı, sosyal medyada başarıyla yönetilen viral pazarlama kampanyası örnekleri arasındadır. Ünlü kişiler başlarından aşağı bir kova buzlu su dökerek (ice bucket challenge) bu kampanyaya destek olmuşlardır. Buzlu su dökülmesinin sebebi, buzun kişiye verdiği soğukluk ve şok etkisi ile ALS hastalığının kas felcine neden olması arasında ilişki kurulmasıdır. Kampanyaya destek olan kişiler "birbirlerine meydan okuma" ifadesiyle diğer kişileri başlarından buz kovası dökmek için meydan okumaya davet etmektedir. Eğer diğer kişiler buz kovası dökmek istemezse ALS Derneği için bağışta bulunmaları beklenmektedir. Bu kampanyada hem diğer kişileri meydan okumaya davet ederek hastalığın kişiler arasında bilinirliğinin yayılmasını sağlamak hem de hastalığı olan kişilere maddi destekte bulunmak amaçlanmaktadır. Böylece viral pazarlama yoluyla ALS hastalığına yönelik farkındalık artırılmaktadır.

Viral pazarlamanın bir başka örneği ise küresel bir halk sağlı̆̆ sorunu olan gençlerde tütün kullanımı konusuna yöneliktir. Sağlı eğitimcileri internet tabanlı teknolojileri kullanarak tütün kullanımını önlemeyi amaçlamaktadır. Ancak internet üzerinden yapılan viral pazarlamanın sağlığın teşviki açısından etkin olup olmadığı belirsizdir. Ip et al. (2014, s. 7) tarafindan yapılan çalışmada, online oyun temelli (game based advertisements-advergame) bir viral pazarlama kampanyası yoluyla tütün kullanımının önlenmesi amaçlanmıştır. Ayrıca, çevrimiçi bir oyunda yapılan bir yarışmayla tütünle ilgili sağlık bilgileri sorulmuş ve bu oyunların tütün farkındalığ 1 oluşturmada etkili bir yol olduğu belirlenmiştir. Çalışmada, internet viral pazarlamasının sağlık eğitimi için çok büyük bir potansiyele sahip olduğu ancak şuan için hala yeterli şekilde kullanılmadığı vurgulanmıştır.

\section{Gerilla Pazarlama}

Gerilla pazarlama beklenmedik bir şekilde halkın marka, ürün veya hizmet bilincini artırmanın bir yolu şeklinde ifade edilmektedir (Lun ve Yazdanifard, 2014, s. 13). Bu pazarlama tekniği esas olarak düşük düzeyde finansal kaynağa sahip, ancak yaratıcı ve entelektüel kaynakları çekmeyi amaçlayan bir pazarlama türü olarak tanımlanmaktadır. Gerilla pazarlamada cesur ve modern fikirlere daha fazla önem verilmektedir ve para yerine zaman, enerji, hayal gücü ve bilgi yatırımları teşvik edilmektedir (Išoraité, 2018, s. 1). Gerilla pazarlamasının örnekleri arasında marka yazılı mendil paketleri gibi ücretsiz sokak eşantiyonları vermek, bir asansörde insanlara bir üründen bahsetmek için oyuncu tutmak veya bir kaldırıma tebeşirle bir pazarlama mesajı yazmak yer almaktadır. Gerilla pazarlama, potansiyel bir hedef gruba ulaşmada çok etkili olabilmekle birlikte bunların uygulanmasının veya etkilerinin izlenmesinin zor olduğu ifade edilmektedir (Jain, 2010, s. 427).

Dünya giderek daha fazla dijitalleştikçe, sağlık kurumları da çağa ayak uydurmaktadır ve sağlık kurumlarında pazarlamanın önemi artmaktadır. Gerilla pazarlama, geleneksel pazarlamanın ötesine geçerek, geleneksel olmayan yöntemler ile hastanelere rekabet gücü ve mevcut hastalar arasında daha güçlü bir topluluk duygusu yaratabilmektedir (Warren, 2018). 
Gerilla pazarlamada inovasyon ve yaratıc1lık öne çıkan kavramlardır. Sağlık hizmetlerinde gerilla pazarlaması ilkelerini kullanmak, sağlı eğitiminde, sağlık politikasında ve sosyal değişimde yeni başarılar getirebilmektedir (Galer-Unti, 2009). Sağlık sektöründe gerilla pazarlama; alkollü araç kullanımının önlenmesi ve cilt kanserinin azaltılması için güneş koruyucu kremlerin kullanımını teşvik etme ve tütün kullanımını azaltma gibi kampanyalarda kullanılmaktadır (Cinnamon, 2014, s. 25).

Türkiye'de sağlık hizmetlerinin doğası düşünüldüğünde gerilla pazarlama stratejilerini uygulamak zorlaşmaktadır. Bunun sebebi gerilla pazarlama ile kişisel mahremiyetin ihlal edilebilmesidir. Hastaların hastalıkları ile ilgili web sitelerden araştırma yaptıktan sonra bu konuda istenmeyen elektronik postalar (spamlar) almaları, birileri tarafindan takip edildiklerini düşünmelerine yol açabilmektedir ve bu durum rahatsız edici olabilmektedir. Çoğunlukla kişiler spam şeklinde gelen elektronik postaları okumadan silmektedir. Bununla birlikte, sağlık hizmetlerinin ulaştırılması yerel düzeyde gerçekleştirilmektedir ve internet kullanmayan sağlık tüketicileri de bulunmaktadır (Tengilimoğlu, 2012, s. 356). Bu sebeple gerilla pazarlamasi stratejileri ulusal düzeyde sağlık hizmetlerinde tam olarak başarılı olamamaktadır. Ancak yakın gelecekte sağlıkta sosyal programların duyurulmasında ve hastaların sağlık farkındalığını artırmada gerilla pazarlamadan faydalanılabileceği düşünülmektedir.

Her ne kadar gerilla pazarlamanın doğası Türkiye'de tartışmalı gibi görünse de, uygulamada örneklerine rastlamak mümkündür. Örneğin Türkiye'de bir kozmetik markası meme kanserine yönelik farkındalık yaratmak amacıyla bazı ürünlerini "pembe kurdele" sembolüyle satışa sunmuştur. $\mathrm{Bu}$ ürünlerden elde edilen satış geliri, hastanelere bağışlanan mamografi cihazlarının finanse edilmesinde kullanılmıştır (Balıkçığlu ve Karacaoğlu, 2007, s. 130; Kaleli, 2018, s. 328). Dolayısıyla, Türkiye'de halk sağlığını geliştirmek ve sağliklı davranışları teşvik etmek amacıyla bu pazarlama türü kullanılabilir. Sağlıksız davranışlar konusunda toplumun caydırılması amacıyla yaratıcı reklamlar planlanabilir. Alkollü araç kullanmak yerine taksiye binmeyi, egzersiz yapmayı ya da cilt kanserinden korunmak için temiz içerikli kozmetik ürünlerine yönelmeyi teşvik eden gerilla pazarlama uygulamaları yapılabilir. Gerilla pazarlamanın en dikkat çeken özelliklerinden biri yaratıcılık ve yeniliktir. Yaratıcılığa ve yeniliğe sosyal medya kampanyaları ve video paylaşım platformları katkı sağlayabilir.

\section{Dijital Pazarlama}

Dijital pazarlama, ürünleri veya hizmetleri dijital kanalları kullanarak tanıtan bir pazarlama türüdür. İnternet kullanımını gerektirmeyen kanallar, cep telefonları, sosyal medya pazarlaması, görüntülü reklamcılık, arama motoru pazarlaması ve diğer birçok dijital ortamdan dijital pazarlama yapilabilmektedir (Yasmin et al. 2015, s. 69-70).

Pek çok endüstri, dijital pazarlamayı hedef kitlelerine ulaşmak ve daha etkili bir şekilde iletişim kurmak için bir araç olarak benimsemiş olsa da, özellikle sağlık sektörü dijital stratejileri benimsemede yavaş ilerlemektedir. Sağlık hizmetlerinde hasta gizliliği ve mahremiyet endişeleri bulunmaktadır. Aynı zamanda birçok sağlık hizmeti pazarlamacısı, değişime isteksiz olan hastane pazarlama/halkla ilişkiler birimleriyle uğraşmanın getirdiği zorluklarla karşı karşıyadır. Ancak sağlık sektöründe pazar payını artırmak, şeffaflık yaratmak, performansı geliştirmek ve hasta katılımını artırmak için dijital pazarlamayı kullanma konusunda çeşitli firsatlar bulunmaktadır (Hambelton, 2016).

Sağlık sektöründe çeşitli dijital pazarlama stratejileri bulunmaktadır. Kolay gezinmeyi sağlayan web siteleri, sağlık bilgisi arayan hastalar için hasta odaklı ve kullanımı kolay olanaklar sunmaktadır. Uluslararası alanda "Mayo Clinic" bu başarılı sitelerden biridir. Bilgilendirici bloglar da sağlık sorunları olan bireyler için sorulara cevaplar, hızlı ipuçları ve doktora gitmeden alabilecekleri tavsiyeler ile faydalı olmaktadır. Kaynağı belli elektronik postalar, kitlenin ilgisini en iyi şekilde çekebilmek için kişiselleştirilmiş bilgileri içeren dijital pazarlama stratejisidir. Sağlık hizmeti tüketicilerinin giderek daha fazla görsel içeriğe yönelmesi, sağlık hizmetlerinin eğiten ve ilham veren videolar yoluyla hastalara ulaştırılmasını kolaylaştırmaktadır. Bu videolar 
aracılığıyla hekimlerin uzmanlık alanlarıyla ilgili bilgi edinilebilmektedir. Video aracılı̆̆ıyla bir sağlık sorunu ile ilgili bilgi veren hekim, hastayı rahatlatabilmekte ve ona güven verebilmektedir. Ayrıca hasta o hekimden hizmet alacaksa, öncesinden hekimin yüz ifadelerini, tavırlarını ve hatta sesini duyarak hizmet almaya gittiğinde kendini daha rahat hissedebilmektedir. Ayrıca sosyal medya kullanımı, sağlı tüketicileri ile bağlantı kurmada ve sağlık kurumunun tanıtımının yapılmasında önemli firsatlar sağlayan dijital pazarlama stratejileri arasında yer almaktadır (Eddine, 2018).

Dijital pazarlama, sağlık endüstrisinin gelişmesine yardımcı olmaktadır. Arama motorları bir araç olarak kullanılarak, hedeflenmiş sosyal bilgiler yaratılarak, hastalar sosyal medyaya yönlendirilerek ve çeşitli verilerden yararlanılarak hastaların katılımı ve sadakati geliştirilebilmektedir. Hâlihazırda sağlık hizmetleri pazarlamasının göreceli olarak yeni bir yönü olan dijital pazarlama, sağlık hizmetleri faaliyetlerinin seyrini değiştirmektedir. Dijital pazarlama büyümeye ve gelişmeye devam ettikçe, sağlik sektöründe bu pazarlama stratejileri daha fazla takip edilecektir (Girardi, 2017).

Sağlık sektöründe başta Sağlık Bakanlığı olmak üzere birçok sağlık kurumu ve kuruluşu, sosyal medya platformlarını kullanmaktadır ve düzenli şekilde güncel paylaşımlar yapmaktadır. Türkiye'de reklam yaptırımları bulunmakla birlikte, birçok sosyal medya platformu, hekimlerin tedavi ve ameliyat videolarını paylaşarak sağlık tüketicilerine kendilerini tanıtmaya yönelik bir zemin hazırlamaktadır. Sosyal medya kanalları aracılığıyla hekimler kadın hastalıkları ve doğum klinikleri, tüp bebek tedavisi, estetik cerrahi gibi birçok alanda dijital tanıtım ve pazarlama tekniklerini kullanabilmektedir.

Türkiye'de sağlık sektöründe reklam yaptırımları göz önünde bulundurulduğunda, birçok sağlık kuruluşu veya sağlık profesyoneli dijital ortamda başka çözüm önerilerine yönelmektedir. Örneğin arama motoru optimizasyonu (search engine optimization) bu çözümlerden biri olmaktadır. Bu uygulamalar, belirli bir semptom, hastalık veya sağlık hizmeti için dijital ortamda arama yapan tüketiciye o sağlık kuruluşunu veya sağlı profesyonelini tanıtmaya yönelik uygulamalardır. Sağlık tüketicisi arama yaptığında arama motorunda o hekime veya kuruluşa daha hızlı ulaşabilmektedir. Böylece o kişinin tanıtım ve hizmetlerinin satış potansiyeli artabilmektedir. Ayrıca, Türkiye'de sağlık hizmetlerinde dijital pazarlamayı geliştirmeye yönelik birçok mobil uygulama dikkat çekmektedir. Sağlık kurum ve kuruluşlarından sağlık hizmeti almak isteyen hastalar, mobil cihazlar aracilığıla randevu alabilmektedir. Hastanelerde hastaların hekimleri ile kolayca iletişim kurabilecekleri, sorularını sorabilecekleri ve tavsiye alabilecekleri dijital platformlar oluşturulmaktadır.

Türkiye'de dijital iletişim kanallarının sağlık turizminde kullanımına odaklanan bir çalışmada, hastanelerin dijital iletişim kanallarında çeşitli bilgi alışverişinde bulundukları, ancak bu ağların etkileşim kurmak için yeterince kullanılmadığ 1 ortaya konulmaktadır. Bir başka ifadeyle, araştırma bulgularına göre sağlık turizminde dijital iletişim kanalları sadece bilgi aktarma aracı olarak kullanılmaktadır. Ancak, bireyler uluslararası zeminde sağlık hizmetleri almak istediklerinde gidecekleri ülke, daha önce tedavi olanların memnuniyet düzeyleri ve tıbbi teknolojinin gelişmişliği gibi konularda bilgi sahibi olmak istemektedir. Bu konuda dijital ortamların en zahmetsiz ve maliyetsiz bilgi kaynağı olduğu düşünüldügünde, dijital pazarlama sağlık turizminin gelişmesinde rol oynayabilmektedir (Öksüz ve Altıntaş, 2017, s. 59). Dolayısıyla, ülkenin ekonomik kalkınmasına önemli katkı sağlayan sağlık turizmine yönelik yapılan tanitımlarda dijital pazarlama tekniklerinden faydalanılabilir.

\section{Sonuç ve Öneriler}

Sağlık hizmetleri, çoğu durumda ertelenemez ve acil nitelikte ortaya çıan hizmetler olması nedeniyle diğer mal ve hizmetlerden ayrılan özelliklere sahiptir. Ancak sağlık hizmetlerinin aynı zamanda arz kaynaklı talep (supply induced demand) oluşturma özelliği de bulunmaktadır. Diğer bir ifadeyle hasta ve sağlık hizmeti üreticisi (hekim) arasındaki asimetrik bilgi nedeniyle gereksiz sağlık hizmeti üretilebilmektedir. Bu nedenle Türkiye dâhil sağlık 
hizmetinde devletin ağırlığının ve katkısının olduğu hizmetlerde pazarlama faaliyetleri sinırlandırılmaktadır ve sinırlandırmaya uymayan kurum ve hizmet sunuculara cezalar verilmektedir. Santas et al. (2017) tarafından gerçekleştirilen çalışmada 2011-2015 yılları arasında Türkiye'de sağlık kurumları ve hizmet sunuculara 904 adet ceza verildiği tespit edilmiştir.

Gereksiz talep oluşabilmekle birlikte özellikle erken teşhis ve tedavinin hayati olduğu hastalıklarda pazarlama faaliyetlerinin önemli olduğu söylenebilir. Özellikle kanser gibi hastalıklar, çoğu durumda hastalık ilerlediğinde belirti vermekte ve teşhis edilmektedir. Bu nedenle bu tür hastalıkların erken teşhisinde ve sağlığın geliştirilmesi hizmetlerinde (sigarayı bırakma, hareketli yaşamın teşviki gibi) bu çalışmada bahsedilen güncel pazarlama yaklaşımlarından daha fazla yararlanılabileceği söylenebilir.

Ülkeler ve sağlık kurumları için gittikçe önemi artan kavramlardan birisi de "sağlık turizmi"dir. Alanyazında derinlemesine tartışıldığı gibi sağlık turizminin ülkeye döviz girişi sağlaması, sağlık kurumunun uluslararası hale gelmesini sağlayarak gittikçe artan maliyet ve rekabetle başa çıkmasında önemli olduğuna inanılmaktadır. Medikal turizm, wellness turizmi, termal turizm gibi farklı türleri olan sağlık turizmi, son yıllarda Türkiye'de özele ait ve kamu hastanelerinde önemli gündem konularından biridir. Ancak yapılan çalışmalarda kamuda sağlık kurumlarında sağlik turizmini geliştirmeye yönelik pazarlama faaliyetlerinin eksikliğine dikkat çekilmektedir. Bu çalışmalarda imaj sorunlarının olduğu ve sağlık turizminde tanıtımın yetersiz olduğu belirtilmektedir (Altsoy ve Taştan Boz, 2019, s. 123; Ö̈zsar1 ve Karatana, 2013, s. 143; Yiğit, 2016, s. 107). Bu sebeple, Türkiye'deki sağlık hizmetleri faaliyetlerini yabancı hasta ve sağlık tüketicilerine duyurmada uluslararası tanıtımlar ve pazarlama faaliyetlerine daha fazla ihtiyaç olduğu söylenebilir. Bu kapsamda sağlık kurum ve kuruluşları, sağlık turizmini geliştirmede bu çalışmada ele alınan pazarlama yaklaşımlarını yasal mevzuat sınırları çerçevesinde kullanabilir.

$\mathrm{Bu}$ çalışmada güncel pazarlama yaklaşımları kavramsal olarak ele alınmış, yaklaşımlara yönelik örnekler ve Türkiye gibi sağlık sektöründe sıkı pazarlama ve reklam yasağı olan ülkelerde bu yaklaşımların kullanımına yönelik örnekler verilmiştir. Gelecekte gerçekleştirilecek çalışmalarda yaklaşımlar uygulamalı olarak incelenebilir ve yaklaşımların başta sağlık turizmi olmak üzere sağlık kurumları ve sektörünün artan rekabet ve maliyetlerle başa çıkmasına yönelik çeşitli uygulamalı çalışmalar gerçekleştirilebilir.

\section{Kaynakça}

Ağırbaş, İ., Akbulut, Y. ve Bayın, G. (2011). Sağllk sektöründe verilen reklam cezalarının sistematik analizi. 5. Sağl1k ve Hastane İdaresi Kongresi, 13-16 Ekim, Fethiye, Türkiye.

Altsoy, S. ve Taştan Boz, İ. (2019). Medikal turizm alanında faaliyet gösteren hastanelerdeki mevcut sorunlar ve çözüm önerileri. Hacettepe Sağllk İdaresi Dergisi, 22(1), 113-134.

Argan, M. ve Tokay Argan, M. (2006). Viral pazarlama veya internet üzerinde ağızdan ağıza reklam: Kuramsal bir çerçeve. Sosyal Bilimler Dergisi, 2, 231-250.

Balıkçıŏlu, B. ve Karacaoğlu, K. (2007). Sosyal bir ürün olarak topluma pazarlanan hayırseverlik: Stratejik hayırseverlik. Gazi Üniversitesi İktisadi ve İdari Bilimler Fakültesi Dergisi, 9(2), 121-141.

Berney, T. (2015). Healthcare marketing: More important than ever. https://blog.vimarketingandbranding.com/healthcare-marketing-more-important-than-ever (Erişim tarihi: 9.11.2018).

Carter, R. (2018). Six healthcare marketing ideas to cure your social media woes. https://sproutsocial.com/insights/healthcare-marketing-ideas/ (Erişim tarihi: 09.11.2018). 
Cinnamon, K. (2014). The efficacy of guerrilla advertising on public health issues. The Elon Journal of Undergraduate Research in Communications, 5(1), 24-34.

Cooper, P. D. (1994). What is health care marketing, P.D. Cooper, (Ed), In health care marketing: A foundation for managed quality. USA: Jones \& Bartlett Learning.

Corbin, C.L., Kelley, S.W. ve Schwartz, R.W. (2001). Concepts in service marketing for healthcare professionals. The American Journal of Surgery, 181(1), 1-7.

Değirmen, G.C. ve Şardağı, E. (2016). Nöropazarlama uygulamalarının etik bağlamında değerlendirilmesi. Akdeniz Üniversitesi İletişim Fakültesi Dergisi, 25, 140-160.

Eddine, L.N. (2018). Six keys to a strong healthcare digital marketing strategy. https://www.kunocreative.com/blog/strong-healthcare-digital-marketing-strategy (Erişim tarihi: 8.11.2018).

Fisher, C.E., Chin, L. ve Klitzman, R. (2010). Defining neuromarketing: practices and professional challenges. Harvard Review of Psychiatry, 18(4), 230-237. doi: 10.3109/10673229.2010.496623

Flores, J., Baruca, A. ve Saldivar, R. (2014). Is neuromarketing ethical? consumers say yes. consumers say no. Journal of Legal, Ethical and Regulatory Issues, 17(2), 77-91.

Galer-Unti, R.A. (2009). Guerilla advocacy: Using aggressive marketing techniques for health policy change. Health Promotion Practice, 10(3), 325-327. doi: 10.1177/1524839909334513

Girardi, C. (2017). The evolving role of digital marketing in healthcare. https://www.evariant.com/blog/evolving-role-digital-marketing-healthcare (Erişim tarihi: 11.11.2018)

Girişken, Y. (2012). The analysis of stuffy nose. Mediacat, 214(11), 136-40.

Gosselin, P. ve Poitras, P. (2008). Use of an Internet "viral" marketing software platform in health promotion. Journal of Medical Internet Research, 10(4), 1-13. doi:10.2196/jmir.1127

Hambelton, K. (2016). Why is digital marketing critical in healthcare? https://www.beckershospitalreview.com/hospital-management-administration/why-is-digitalmarketing-critical-in-healthcare.html (Erişim tarihi: 8.11.2018)

Harris, J.M., Ciorciari, J. ve Gountas, J. (2018). Public health social media communications and consumer neuroscience. Cogent Psychology, 5(1). doi:10.1080/23311908.2018.1434058

Ho, J.Y. ve Dempsey, M. (2010). Viral marketing: Motivations to forward online content. Journal of Business Research, 63(9-10), 1000-1006. doi:10.1016/j.jbusres.2008.08.010

Ip, P., Lam, T.H., Chan, S.S.C., Ho, F.K.W., Lo, L.A., Chiu, I.W.S., Wong, W.H.S. ve Chow, C.B. (2014). Use of Internet viral marketing to promote smoke-free lifestyles among chinese adolescents. PLoS One, 9(6), e99082, 1-9. doi:10.1371/journal.pone.0099082

Išoraitè, M. (2018). Guerilla marketing features. Ecoforum Journal, 7(1), 1-6.

Jain, A. (2010). Temptations in cyberspace: New battlefields in childhood obesity. Health Affairs, 29(3), 425-429. doi:10.1377/hlthaff.2010.0107

Kaleli, S. (2018). Sosyal pazarlamada gerilla uygulamalar. Trakya Üniversitesi Sosyal Bilimler Dergisi, 20(2), 313-336. doi:10.26468/trakyasobed.464787

Karafakıoğlu, M. (1998). Sağlık hizmetleri pazarlaması. İstanbul: İstanbul Üniversitesi İşletme Fakültesi Yayınları.

Kumar, H., Mathur, N. ve Jauhari, S. (2016). Role of emergengening neuromarketing techniques in advertising with particular reference to Indian medical tourism industry: A discussion and 
agenda for future research. Biannual Journal on Commerce Arts Education Sociology and Humanities, 3(6), 1-11.

Leskovec, J., Adamic, L.A. ve Huberman, B.A. (2007). The dynamics of viral marketing. ACM Transactions on the Web, 1(1), 1-39. doi:10.1145/1232722.1232727

Lim, W.M. ve Ting, D.H. (2012). Healthcare marketing: Contemporary salient issues and future research directions. International Journal of Healthcare Management, 5(1), 3-11. doi:10.1179/204797012X13293146890048

Lun, O.K. ve Yazdanifard, R. (2014). Guerrilla marketing: A successful business model for Xiaomi, Global Journal of Human-Social Science: Economics, 14(7), 12-17.

Nurdağ Silkü, S. ve Şar, S. (2015). Nöropazarlama tekniklerinin eczacılık alanında kullanılması. Turkiye Klinikleri Journal of Literature Pharmacy Sciences, 4(1), 37-42. doi:10.5336/pharmsci.2015-45567

Orzan, G., Zara, I.A. ve Purcarea, V.L. (2012). Neuromarketing techniques in pharmaceutical drugs advertising. A discussion and agenda for future research. Journal of Medicine and Life, 5(4), 428-432.

Öksüz, B. ve Altıntaş, V. (2017). Sağlık turizminde dijital iletişim kanallarının kullanımı. Seyahat ve Otel Issletmeciliği Dergisi, 14(1), 59-75.

Özsarı, H. ve Karatana, Ö. (2013). Sağlık turizmi açısından Türkiye'nin durumu. Kartal Eğitim ve Araştırma Hastanesi Tıp Dergisi, 24(2), 136-144. doi:10.5505/jkartaltr.2013.69335

Parvanta, C., Nelson, D.E., Parvanta, S.A. ve Harner, R.N. (2011). Essentials of public health communication. USA: Jones \& Bartlett Publishers.

Racine, E., Bar-Ilan, O. ve Illes, J. (2005). fMRI in the public eye. Nature Reviews Neuroscience, 6(2), 159-164. doi:10.1038/nrn1609

Sample, I. ve Adam, D. (2003). The brain can't lie: Brain scans reveal how you think and feel and even how you might behave. The Guardian. https://www.theguardian.com/science/2003/nov/20/neuroscience.science (Erişim tarihi: 10.11.2018)

Santas, F., Santas, G. ve Ugurluoglu, O. (2017). Advertising bans in the health sector: A case study. International Journal of Healthcare Management. doi:10.1080/20479700.2017.1412875

Tengilimoğlu, D. (2012). Sağllk hizmetleri pazarlaması. Ankara: Siyasal Kitabevi.

The Lancet Neurology. (2004). Neuromarketing: Beyond branding, The Lancet Neurology, 3, 71.

Walji, M.F., Valenza, J.A. ve Zhang, J. (2009). E-health marketing. E.V. Wilson, (Ed), In patientcentered e-health. USA: Information Science Reference.

Warren, J. (2018). How guerrilla marketing lessons make hospital marketing better. https://marketingyourhospital.com/how-guerrilla-marketing-lessons-makehospitalmarketing-better/ (Erişim tarihi: 10.11.2018).

Wilson, R.F. (2018). The six simple principles of viral marketing. https://www.practicalecommerce.com/viral-principles (Erişim tarihi: 9.11.2018).

Yasmin, A., Tasneem, S. ve Fatema, K. (2015). Effectiveness of digital marketing in the challenging age: An empirical study. International Journal of Management Science and Business Administration, 1(5), 69-80.

Yiğit, V. (2016). Kamu hastanelerinde medikal turizminin gelişimini etkileyen faktörler. Süleyman Demirel Üniversitesi Vizyoner Dergisi, 7(15), 107-119. 


\section{ETİK ve BİLIMSEL İLKELER SORUMLULUK BEYANI}

$\mathrm{Bu}$ çalışmanın tüm hazırlanma süreçlerinde etik kurallara ve bilimsel atıf gösterme ilkelerine riayet edildiğini yazar(lar) beyan eder. Aksi bir durumun tespiti halinde Afyon Kocatepe Üniversitesi Sosyal Bilimler Dergisi'nin hiçbir sorumluluğu olmayıp, tüm sorumluluk makale yazarlarına aittir. 